\title{
The effects of fatigue and pain on daily life activities in systemic lupus erythematosus
}

\author{
Sistemik lupus eritematozus'da yorgunluk ve ağrının günlük yaşam aktivitelerine etkisi
}

\section{Filiz ÖZEL, Gülümser ARGON}

\begin{abstract}
Summary
Objectives: The aim of this study was to determine the effects of pain and fatigue on daily life activities of systemic lupus erythematosus (SLE) patients.

Methods: The study sample included 74 SLE patients who presented to outpatient departments of a university hospital and two local hospitals between 30.9.2009 and 15.5.2010. Data was collected using the Fatigue Severity Scale, Katz's Activity's Daily Living Index, Lawton and Brody's Instrumental Activities of Daily Living, and the McGill Pain Questionnaire.

Results: The mean scores were 6.0 (fatigue) on the Fatigue Severity Scale, 18.0 (independent) on the Daily Life Activities Index, 24.0 (independent) on the Instrumental Daily Life Activities Index, and 1.56 (discomforting) on the McGill Pain Scale for pain felt at the moment of questioning. A low-level negative relationship was observed between the scores on the Fatigue Severity Scale and the Daily Life Activities Index $(p<0.05, r=-0.298)$, and between Fatigue and Instrumental Daily Life Activities scores $(p<0.05, r=-0.354)$. A medium-level positive relationship was observed between the scores on the Fatigue Severity Scale and the McGill Pain Scale $(p<0.05, r=0.478)$.
\end{abstract}

Conclusion: This study determined that pain and fatigue affected the daily lives of SLE patients. The study should be repeated on a larger sample.

Key words: Daily life activities; fatigue; pain; systemic lupus erythematosus.

\section{Özet}

Amaç: Bu araştırma, sistemik lupus eritematozuslu (SLE) hastalarda oluşan ağrı ve yorgunluğun günlük yaşam aktivitelerine etkisini belirlemek amacıyla planlandı.

Gereç ve Yöntem: Araştırmanın evrenini 30 Eylül 2009-15 Mayıs 2010 tarihleri arasında bir üniversite hastanesi ve iki ilçe hastanesi dahiliye polikliniklerine başvuran SLE hastaları oluşturdu. Araştırmanın verileri, araştırmacı tarafından Yorgunluk Şiddeti Ölçeği, Katz'in Günlük Yaşam Aktiviteleri İndeksi, Lawton ve Brody'nin Enstrümental Günlük Yaşam Aktiviteleri Indeksi ve McGill Ağrı Ölçeği ile toplandı.

Bulgular: Araştırmada Yorgunluk Şiddeti Ölçeği puan ortalaması 6.0 (yorgun); Günlük Yaşam Aktiviteleri İndeksi puan ortalaması 18.0 (bağımsız); Enstrümental Günlük Yaşam Aktiviteleri İndeksi puan ortalaması 24.0 (bağımsız); McGill Ağı Ölçeği'ne göre sorulan andaki ağrı puan ortalaması 1.56 (rahatsız edici) olarak saptandı. Yorgunluk Şiddeti Ölçeği ile Günlük Yaşam Aktiviteleri İndeks puanları arasında düşük düzeyde negatif bir ilişki olduğu bulundu. Yorgunluk Şiddeti Ölçek puanı arttıkça Günlük Yaşam Aktiviteleri Indeks puanı azalmakta idi ( $p<0.05, r=-0.298)$. Yorgunluk ile Enstrümental Günlük Yaşam Aktiviteleri Indeks puanları arasında düşük düzeyde negatif yönde bir ilişki bulundu. Yorgunluk Şiddeti Ölçek puanı arttıkça Enstrümental Günlük Yaşam Aktiviteleri İndeks puanı azalmakta idi $(p<0.05, r=-0.354)$. Yorgunluk Şiddeti Ölçeği ile Ağrı Ölçeği puanları arasında orta düzeyde pozitif yönde anlamlı bir ilişki olduğu bulundu. Yorgunluk Şiddeti Ölçek puanı arttıkça ağrı şiddeti puanı da artmakta idi $(p<0.05, r=0.478)$.

Sonuç: Bu araştırma ağrı ve yorgunluğun SLE'li hastaların günlük yaşam aktivitelerine etki ettiğini göstermiştir. Bu araştırmanın daha büyük örneklemlerde tekrarlanması önerilir.

Anahtar sözcükler: Günlük yaşam aktiviteleri; yorgunluk; ağrı; sistemik lupus eritematozus.

\section{Department of Internal Medicine Nursing, Ege University Faculty of Nursing, Izmir, Turkey}




\section{Introduction}

Systemic lupus erythematosus (SLE) is a systemic, chronic, inflammatory, autoimmune disease in which pathogenic auto-antibodies and immune complexes cause tissue damage in the target organ. Although SLE can occur in both sexes at any age, it appears to be more common in women and in people between the ages of 20-40. At this age, female to male ratio is 9:1 is. The prevalence ranges from 4 to 250 per 100.000 people. The incidence is reported to be $15-50$ per 100.000 people. ${ }^{[1]}$ The hospitalization rate for SLE patients is $20-25 \%$ a year. Among the causes of hospitalization are SLE treatment, SLE complications, infections and worsening of the conditions. Patient care during hospitalization is expensive. ${ }^{[2]}$ The two-year survival rate of patients with SLE is $90-95 \%$, 5 -year survival rate is $82-90 \%, 10$-year survival rate is $71-80 \%$ and 20 -year survival rate is $63-75 \%{ }^{[3]}$ When the etiology of SLE is considered, environmental, hormonal and genetic factors appear to play part. For the development of SLE, a genetic basis is absolutely essential. However, genetic factors alone are not sufficient for the development of SLE, and other factors should also take effect. ${ }^{[4]} \mathrm{Pa}$ tients with SLE often experience changes in physical functions and exacerbation of the disease. Patients also suffer depression and despair (hopelessness) due to unexpected symptoms, effects of the disease and uncertain (indefinite/unspecified) prognosis. ${ }^{[5]}$ Moreover, symptoms appearing in SLE patients can lead to limitations (restrictions) in physical and psychological functions, family conflicts, social isolation, anxiety, depression, and reduction in working ability, income and self-esteem. SLE leads to a decrease in working ability and productivity, and an increase in financial problems. ${ }^{[6]}$

General, mucocutaneous, musculoskeletal, cardiovascular, gastrointestinal, lymphoreticular, neuropsychiatric and ocular symptoms develop in SLE. ${ }^{[1]}$ During the clinical course of SLE, fatigue, fever and weight loss occur. ${ }^{[7]}$ Fatigue is a common clinical symptom and is seen in $80-100 \%$ of the patients with SLE. Fatigue usually occurs before the other findings develop and it is the most important problem in one-third of patients. ${ }^{[8,9]}$ Fatigue is a constant problem and causes a decrease in functions. ${ }^{[10,11]}$ Fatigue affects activities, physical functions and working life and thus causes a decrease in the quality of life.
${ }^{[12,13]}$ Fatigue affects many activities. ${ }^{[14]}$ SLE can cause many problems in patients. Extreme fatigue, pain, photosensitivity, and several other negative factors adversely affect a person's life and activities of daily living. ${ }^{[15,16]}$ Pain is the most common symptom of rheumatic diseases and interferes with life and daily living activities of a person with SLE. ${ }^{[17]}$ It has been revealed that patients with SLE experience reduction in strength and have difficulty in doing activities of daily living due to pain. ${ }^{[15]}$ In a study conducted by Martin et al., it was determined that the level of the effects of fatigue on body functions and structure was $97.9 \%$, the effect of combined pain was $80.6 \%$ and the effect of pain in body parts was $79.6 \% .{ }^{[18]}$ In a study conducted by Katz et al. (2008), almost twothirds of the patients with SLE faced continuous or periodic problems while conducting activities at work or at home. SLE has been shown to be a disease which affects working life to a great extent and increases failure in business three or fourfold, which becomes even more when the disease is accompanied with neuropsychiatric problems. ${ }^{[19]}$ Therefore, for patients with SLE, potential diversity of the disease, the severity of the symptoms and unexpected circumstances and changes should be decreased, and decline in living conditions should be prevented. ${ }^{[5]}$ Current treatments do not provide permanent cure for SLE, but improve the symptoms and prevent the patient's current condition from becoming worse. ${ }^{[7]}$ Therefore, an appropriate planning should be made in order to bring acute and severe exacerbations of the disease under control, to suppress the symptoms reasonably enough to prevent the side effects of medication and to develop maintenance strategies. The importance of nursing care in symptom management should not be underestimated. The importance of nursing care as the reduction or prevention of exacerbations, provision of emotional support and training for individuals and families. The importance of holistic approach in life style changes, patient care and adaptation to a chronic illness has been emphasized..$^{[7,20-22]}$

In our country, no study has been conducted on fatigue and pain despite their high prevalence in SLE patients and effects on activities of daily living and quality of life. What is more, the number of studies conducted on SLE in our country is very few. This study was planned as a descriptive one in order to 
assess the effects of fatigue and pain on daily living activities of patients with SLE.

\section{Materials and Methods}

Data from the study were collected with the Fatigue Severity Scale, Katz Index of Independence in Activities of Daily Living, Lawton and Brody's Instrumental Activities of Daily Living Scale (IADL), the McGill Pain Questionnaire and the Patient Identification Form which was especially developed by the researchers by screening the relevant literature. Face-to-face interviews were conducted by the first author. The interviews lasted between 30 and $60 \mathrm{~min}$.

The study sample included 74 SLE patients who presented to outpatient departments of a university hospital and two local hospitals between 30.9.2009 and 15.5.2010. The participants were informed about the general nature of the study verbally before the interviews started. Our sample included SLE patients who agreed to participate in the research.

Of the patients who comprised the study sample, $8.1 \%$ were under the age of $20,54.1 \%$ were between the ages of $20-40$, and $37.8 \%$ were over the age of 40 , and $89.2 \%$ were females and $10.7 \%$ males.

\section{Instruments}

Patient Identification Form: The form includes sociodemographic information regarding SLE patients' age, gender, marital status, number of children, education level, occupational status, and monthly income level, and the duration of the disease, its symptoms and effects on the patient, and the affected organs.

Fatigue Severity Scale (FSS): FSS is a short and simple tool developed by Krupp in 1989. It consists of nine questions related to fatigue. The total score is calculated as the mean score of 9 items. As FSS increases, so does the effect of fatigue on daily life. If the FSS score is higher than 4, it is considered that fatigue is present. FSS score higher than 4 means that fatigue affects daily life at a moderate-severe level. Options for answers: $1=$ strongly disagree, $2=$ disagree, $3=$ tend not to participate in, $4=$ undecided, $5=$ tend to participate in, $6=$ agree, $7=$ strongly agree $^{[23]}$

McGill Pain Questionnaire (MPQ): It is a form that is applied in order for the patient to express what his/her pain is like through specific and meaningful words. ${ }^{[24]}$ During the measurements conducted with the McGill Pain Questionnaire, the location and severity of the pain, the feeling it causes on the patient, and the level of the pain the patient can tolerate are determined. ${ }^{[25]}$

Katz Index of Independence in Activities of Daily Living (Katz ADL): The data were obtained using the ADL scale developed by Katz et al (1963). The ADL index consists of six questions on such activities as bathing, dressing, toileting, transferring, continence, feeding. If an individual performs ADLs independently, he/she gets 3 points. If he/she performs them with assistance he/she gets 2 points. If he/she is unable to perform them he/she gets 1 point. In ADL index, a point between 0 and 6 means dependency, between 7 and 12 means semi-dependency, and between 13 and 18 means independency.

Lawton and Brody's Instrumental Activities of Daily Living Scale (IADL): The scale includes 8 items: ability to use telephone, shopping, food preparation, housekeeping, laundry, mode of transportation, responsibility for own medications, ability to handle finances. If an individual performs ADLs independently, he/she gets 3 points. If he/she performs them with assistance he/she gets 2 points. If he/she is unable to perform them he/she gets 1 point. In the IADL, a point between 0 and 8 means dependency, between 9 and 16 means semi-dependency, and between 17 and 24 means independency.

\section{Ethical consideration}

Ethical approval was obtained from the School of Nursing and hospital administration. To use the Fatigue Severity Scale and the McGill Pain Questionnaire in this study, the authors' permission was obtained. In addition, patients were informed about the purpose of the study, and their written consents were received.

\section{Data analysis}

The data were analyzed by using a SPSS 16.0 statistical software package. Demographic and descriptive information about patients, pain and fatigue levels were presented in numbers and percentages. Correlations between the scales were also examined. 
Table 1. Distribution of SLE patients in terms of disease duration

\begin{tabular}{lcc}
\hline Disease duration (month/year) & $\mathbf{n}$ & $\%$ \\
\hline Less than 1 year & 3 & 4.1 \\
$1-10$ years & 58 & 78.3 \\
11 or more years & 13 & 17.6 \\
\hline
\end{tabular}

SLE: Systemic Lupus Erythematosus.

Table 2. Distribution of the symptoms observed in patients with SLE

\begin{tabular}{lcc}
\hline Symptoms* & $\mathbf{n}$ & $\%$ \\
\hline Malar rash & 66 & 89.1 \\
Photosensitivity & 64 & 86.5 \\
Oral ulcers & 13 & 17.6 \\
Arthritis & 68 & 91.8 \\
Serositis & 3 & 4.0 \\
Renal disorders & 14 & 18.9 \\
Neurological disorders & 7 & 9.4 \\
Hematologic disorders & 5 & 6.8 \\
Immunologic disorders & 6 & 8.1 \\
Fever & 19 & 25.7 \\
Fatigue & 67 & 90.5 \\
Anorexia (loss of appetite) & 24 & 32.4 \\
Hair loss (alopecia) & 6 & 8.1 \\
Weight loss & 14 & 18.9 \\
ANA positivity & 58 & 78.4 \\
Pain & 73 & 98.5 \\
\hline
\end{tabular}

SLE: Systemic lupus erythematosus.

\section{Results}

Of the patients who participated in the study, $4.1 \%$ had the disease less than 1 year, 78.3\% 1-10 years and $17.6 \% 11$ years or over. When the mean disease duration for the group was considered, it was found to be $1-5$ years for $51.4 \%$ (Table 1 ).

When the symptoms of the patients were considered, of them, $89.1 \%$ were determined to have butterfly rash, $86.5 \%$ photosensitivity, $17.6 \%$ oral ulcers, $91.8 \%$ arthritis, $4.0 \%$ serositis, $18.9 \%$ renal disorders, 9.4\% neurological disorders, $6.8 \%$ hematologic disorders, $8.1 \%$ immunologic disorders, $25.7 \%$ fever, $90.5 \%$ fatigue, $32.4 \%$ anorexia, $8.1 \%$ hair loss (alopecia), $18.9 \%$ weight loss, $78.4 \%$ ANA positivity and 99.5\% pain (Table 2 ).
Table 3. Patients' opinions regarding the effects of the disease on their business and social lives

\begin{tabular}{lcc}
\hline $\begin{array}{l}\text { Do you think you're the disease } \\
\text { affects your business and social life? }\end{array}$ & n & \% \\
\hline Yes & 49 & 66.2 \\
Partly & 24 & 32.4 \\
No & 1 & 1.4 \\
Total & 74 & 100 \\
\hline
\end{tabular}

Table 4. Average scale scores

\begin{tabular}{lcc}
\hline Scales & $\mathbf{n}$ & Mean \pm SD \\
\hline Fatigue Severity Scale & 74 & $5.8 \pm 1.2$ \\
$\begin{array}{l}\text { Activities of Daily Living Index } \\
\text { Instrumental Activities }\end{array}$ & 74 & $17.4 \pm 2.0$ \\
$\begin{array}{l}\text { of Daily Living Index } \\
\text { McGill Pain Questionnaire }\end{array}$ & 74 & $22.3 \pm 2.8$ \\
\hline
\end{tabular}

SD: Standard deviation.

When the patients who participated in the study were asked how much the disease affected their work and social lives, $66.2 \%$ stated that it affected their lives, $32.4 \%$ said that it affected their lives partially and $1.4 \%$ said it did not affect their lives (Table 3 ).

In the study the mean scores for Fatigue Severity Scale, Activities of Daily Living Index, Instrumental Activities of Daily Living Index and McGill Pain Questionnaire were found to be as $5.8 \pm 1.2$ (tired), $17.4 \pm 2.0$ (independent), $22.3 \pm 2.8$ (independent) and 1.56 \pm 0.66 (annoying/disturbing) respectively (Table 4).

In the study, it was observed that the mean score of Activities of Daily Living Index for the 40+age group was significantly lower than that of the $20-40$ age group ( $p<0.05)$ whereas the mean scores of the other scales were not significantly different between the age groups ( $p>0.05$ ) (Table 5).

In the study, statistically no significant differences were determined between the mean scores of the scales and gender groups ( $p>0.05$ ) (Table 6).

When the distribution of the average scale scores and disease duration of the study groups were considered, no statistical evaluation was made since the number of subjects was fewer than 3 in those with 
Table 5. Distribution of the mean scores of the scales in terms of age groups

\begin{tabular}{|c|c|c|c|c|c|}
\hline \multirow[t]{2}{*}{ Scales } & \multirow[t]{2}{*}{ Age } & \multirow[t]{2}{*}{$\mathbf{n}$} & \multirow[t]{2}{*}{ Mean \pm SD } & \multicolumn{2}{|c|}{ Paired comparison } \\
\hline & & & & $\mathbf{H}$ & $\mathbf{p}$ \\
\hline \multicolumn{6}{|c|}{ Fatigue Severity Scale } \\
\hline & Under 20 & 6 & $54.0 \pm 8.1$ & 0.893 & 0.641 \\
\hline & $20-40$ & 40 & $51.1 \pm 11.4$ & & \\
\hline & Over 40 & 28 & $53.0 \pm 11.7$ & & \\
\hline \multicolumn{6}{|c|}{ Activities of Daily Living Index } \\
\hline & Under 20 & 6 & $17.0 \pm 2.4$ & 7.432 & 0.024 \\
\hline & $20-40$ & 40 & $17.8 \pm 1.4$ & & \\
\hline & Over 40 & 28 & $16.8 \pm 2.6$ & & \\
\hline \multicolumn{6}{|c|}{ Instrumental Activities of Daily Living Index } \\
\hline & Under 20 & 6 & $22.3 \pm 3.2$ & 3.547 & 0.171 \\
\hline & $20-40$ & 40 & $23.3 \pm 2.0$ & & \\
\hline & Over 40 & 28 & $22.0 \pm 3.5$ & & \\
\hline \multicolumn{6}{|c|}{ McGill Pain Questionnaire } \\
\hline & Under 20 & 6 & $21.2 \pm 3.8$ & 2.507 & 0.286 \\
\hline & $20-40$ & 40 & $18.8 \pm 4.0$ & & \\
\hline & Over 40 & 28 & $19.8 \pm 4.1$ & & \\
\hline
\end{tabular}

SD: Standard deviation.

Table 6. Distribution of mean scores of the scales by gender

\begin{tabular}{|c|c|c|c|c|c|}
\hline \multirow[t]{2}{*}{ Scales } & \multirow[t]{2}{*}{ Gender } & \multirow[t]{2}{*}{$\mathbf{n}$} & \multicolumn{3}{|c|}{ Mann-Whitney U } \\
\hline & & & Mean & $\mathbf{U}$ & $\mathbf{p}$ \\
\hline \multicolumn{6}{|c|}{ Fatigue Severity Scale } \\
\hline & Female & 66 & 38.8 & 175 & 0.114 \\
\hline & Male & 8 & 26.4 & & \\
\hline \multicolumn{6}{|c|}{ Activities of Daily Living Index } \\
\hline & Female & 66 & 37.5 & 262.5 & 0.963 \\
\hline & Male & 8 & 37.3 & & \\
\hline \multicolumn{6}{|c|}{ Instrumental Activities of Daily Living Index } \\
\hline & Female & 66 & 36.9 & 225 & 0.393 \\
\hline & Male & 8 & 42.4 & & \\
\hline \multicolumn{6}{|c|}{ McGill Pain Questionnaire } \\
\hline & Female & 66 & 39.0 & 163 & 0.078 \\
\hline & Male & 8 & 24.9 & & \\
\hline
\end{tabular}

disease duration less than 1 year. Only descriptive values were provided (Table 7).

A low-level negative relationship was observed between the scores on the Fatigue Severity Scale and the Daily Life Activities Index ( $p<0.05, r=-0.298)$, and between Fatigue Severity Scale and Instrumental Daily Life Activities scores $(p<0.05, r=-0.354)$. A me- dium-level positive relationship was observed between the scores on the Fatigue Severity Scale and the McGill Pain Scale $(p<0.05, r=0.478)$ (Table 8).

\section{Discussion}

The study comprised 74 SLE patients, and $54.1 \%$ of the respondents were between the ages of 20 and 
Table 7. Distribution of the average scale scores and disease duration

\begin{tabular}{lccc}
\hline Scales & Disease duration & $\mathbf{n}$ & Mean \pm SD \\
\hline Fatigue Severity Scale & $<1$ year & 3 & $58.3 \pm 8.1$ \\
& $1-10$ years & 58 & $51.7 \pm 10.7$ \\
& $\geq 11$ years & 13 & $51.3 \pm 15.2$ \\
Activities of Daily Living Index & & \\
& $<1$ year & 3 & $14.7 \pm 5.8$ \\
& $1-10$ years & 58 & $17.7 \pm 0.9$ \\
Instrumental Activities of Daily Living Index & $\geq 11$ years & 13 & $16.5 \pm 2.6$ \\
& & & \\
& $<1$ year & 3 & $19.7 \pm 7.5$ \\
McGill Pain Questionnaire & $1-10$ years & 58 & $23.3 \pm 1.7$ \\
& $\geq 11$ years & 13 & $21.2 \pm 3.5$ \\
& & & \\
& $<1$ year & 3 & $18.3 \pm 5.8$ \\
& $1-10$ years & 58 & $19.6 \pm 3.6$ \\
& $\geq 11$ years & 13 & $18.5 \pm 5.6$ \\
\hline
\end{tabular}

SD: Standard deviation.

40. Of the patients included in the study, $89.2 \%$ were females. The results of this study are consistent with those in the literature. In a prospective study conducted by Tüzün et al. (2002), the mean age of the patients was 34.5 and $90 \%$ of the participants were female. ${ }^{[26]}$ Distribution of the patients regarding the disease duration revealed that $4.1 \%$ had the disease for less than 1 year, $78.4 \%$ for $1-10$ years and $17.6 \%$ for 11 or more years. In Tüzün et al.'s study (2002), the disease duration was found to be between 1 month and 22 years, which was consistent with the results of this study. ${ }^{[26]}$

The evaluation of the symptoms suffered by the patients participating in the study revealed that $89.1 \%$ of them had butterfly rash, $86.5 \%$ photosensitiv- ity, $17.6 \%$ oral ulcers, $91.8 \%$ arthritis, $4.0 \%$ serositis, $18.9 \%$ renal disorders, $9.4 \%$ neurological disorders, $6.8 \%$ hematologic disorders, $8.1 \%$ immunologic disorders, $25.7 \%$ fever, $90.5 \%$ fatigue, $32.4 \%$ anorexia, $8.1 \%$ hair loss (alopecia), $18.9 \%$ weight loss and 78.4\% ANA positivity. The results of this study are consistent with those in the literature. In a study performed by Rabbani et al. (2009), it was determined that 30\% had malar rash, $15 \%$ discoid lupus, $6 \%$ photosensitivity, $53 \%$ fever and $22 \%$ alopecia. In the same study, it was determined that approximately $45 \%$ of the patients had renal involvement, almost all the patients had symptomatic arthralgia and approximately $76 \%$ of the patients experienced organ damage, and that the mortality rate was $24 \%$. ${ }^{[27]}$ In Arfaj et al.'s study (2009), of the patients, 82.7\%

Table 8. The relationship between the scales

\begin{tabular}{lcccc}
\hline Scales & $\begin{array}{c}\text { Fatigue } \\
\text { Severity Scale }\end{array}$ & $\begin{array}{c}\text { Activities of } \\
\text { Daily Life Index }\end{array}$ & $\begin{array}{c}\text { Instrumental Activities } \\
\text { of Daily Life Index }\end{array}$ & $\begin{array}{c}\text { McGill Pain } \\
\text { Questionnaire }\end{array}$ \\
\hline Fatigue Severity Scale & & $-0.298^{*}$ & $-0.354^{*}$ & $0.478^{*}$ \\
Activities of Daily Life Index & $-0.298^{*}$ & & $0.945^{*}$ & $-0.341^{*}$ \\
Instrumental Activities of Daily Life Index & $-0.354^{*}$ & $0.945^{*}$ & & $-0.400^{*}$ \\
McGill Pain Questionnaire & $0.478^{*}$ & $-0.341^{*}$ & $-0.400^{*}$ & \\
\hline
\end{tabular}

${ }^{*} p<0.05$. 
had hematologic abnormalities, $80.4 \%$ arthritis and $64.3 \%$ mucocutaneous symptoms, and among the hematologic abnormalities, anaemia was the most common symptom (63.1\%). ${ }^{[28]}$ In a study by Cervera et al. (2009), it was determined that, of the patients, $40 \%$ had malar rash, $24 \%$ alopecia and $19 \%$ of oral ulcerations, and that deformities of the hands and feet are the most common lesions (10\%) seen in patients with SLE. ${ }^{[29]}$ In Mok et al.' study (2009), neuropsychiatric damage was observed in $12 \%$ of the patients with SLE, musculo-skeletal damage in $11 \%$, gonadal damage in $10 \%$, cardiovascular damage in $9 \%$ and dermatological damage in 9\%. ${ }^{[30]}$ In Rabbani et al.'s study (2009), 20 SLE patients developed renal failure and dialysis was initiated, and 2 patients underwent renal transplantation. ${ }^{[27]}$ In Şentürk et al.' study (2003), skin involvement is often the first sign of the disease in $72-85 \%$ of the patients with SLE. ${ }^{[31]}$

The level of fatigue detected in the patients of this study is similar to that in the literature. In Ellison et al.'s study (2006), it was determined that SLE patients suffered depression, pain and fatigue. In the same study, fatigue was observed in $50-100 \%$ of the patients and fatigue was defined as a chronic finding. It was also determined that fatigue led to the deterioration of activities, physical activities, work life and the quality of life. ${ }^{[13]}$ In their study (2007), Huang et al. determined that fatigue is one of the most important symptoms of SLE and that $73.1 \%$ SLE patients experienced fatigue. ${ }^{[32]}$ In their study (2006), Navarra et al. determined that more than $90 \%$ of the patients with SLE suffered fatigue and that fatigue caused several deficiencies in $50 \%$ of the patients. ${ }^{[33]}$

In this study, $99.5 \%$ of the patients suffered pain and the level of the pain at the moment they were questioned was determined as "disturbing" according to McGill Pain Questionnaire. In Greco et al.'s study (2003), the pain rate in patients with SLE was found to be $85 \%$ and $95 \%$ of the pain was due to headaches. ${ }^{[34]}$

Activities of Daily Living Index score in the $40+$ age group was significantly lower than that in the 20-40 age group $(p<0.05)$; on the other hand, no significant difference was determined between the age groups regarding the scores of other scales $(p>0.05)$. The patients of the study were found to be "independent" in terms of the mean scores of the Instrumental Activities of Daily Living index and Activities of Daily Living Index. The results of this study are different from those in the literature, which can be explained with the fact that the study sample included only those patients who presented to the outpatient clinic.

A low-level negative relationship was observed between the scores on the Fatigue Severity Scale and the Daily Life Activities Index, and between the scores of Fatigue Severity Scale and Instrumental Daily Life Activities. A medium-level positive relationship was observed between the scores on the Fatigue Severity Scale and the McGill Pain Scale. In Katz et al.'s study (2008), it was determined that SLE led to continuous or periodic deficiencies in the patients which prevented them from performing their activities of daily living, that SLE affected their work lives to a great extent, that this effect increased when SLE was accompanied with neuropsychiatric problems, and that their social relationships and sex lives were adversely affected by the symptoms of SLE. In the same study, the quality of life of the patients with SLE was investigated, a range of measurements were employed to assess their physical function and/or role functions, and finally it was determined that patients' working lives deteriorated. ${ }^{[19]}$ In Lash's study (1998), it was stated that SLE caused psychological and physical limitations and that fatigue was a terrible experience suffered by female patients with SLE, which led to depression and sleep problems in them. ${ }^{[35]}$ In their studies (2007), Huang et al. state that fatigue can adversely affect daily lives and personal interactions of SLE patients. They also define SLE as a major factor which affects patients' physical health and which decreases their quality of life. ${ }^{[32]}$

\section{Study limitations}

The study included only the patients diagnosed with SLE. The study population was limited to Turkishspeaking, conscious SLE patients who presented to the outpatient clinics of a university hospital and two state hospitals between June 15 and September 15, 2009. In addition, the number of the male patients who participated in the study was insufficient.

\section{Conclusion}

In the study, SLE patients' levels of fatigue, pain, activities of daily living and instrumental activities of 
daily living were measured and the effects of fatigue and pain on activities of daily living were evaluated, and it was determined that pain and fatigue affected SLE patients' daily living activities.

In our country, since there are not enough nursing studies conducted on patients with SLE, it is necessary to carry out such studies more. In the light of the results obtained from this study, it is recommended that education programs should be prepared for patients or nurses so that SLE patients can effectively manage the pain, fatigue and other symptoms they suffer and that they can improve their quality of life.

\section{Conflict-of-interest issues regarding the authorship or article: None declared.}

\section{Peer-rewiew: Externally peer-reviewed.}

\section{References}

1. İliçin G, Biberoğlu K, Süleymanlar G, Ünal S. İç hastalıkları. Ankara: Güneş Kitabevi; 2003.

2. Yazdany J, Gillis JZ, Trupin L, Katz P, Panopalis P, Criswell $L A$, et al. Association of socioeconomic and demographic factors with utilization of rheumatology subspecialty care in systemic lupus erythematosus. Arthritis Rheum 2007;57(4):593-600.

3. Harrison. İç hastalıkları prensipleri. İstanbul: Nobel Tıp Kitabevleri; 2004.

4. Gümüşdiş G, Doğanavşargil E. Klinik romatoloji. İstanbul: Deniz Matbaası; 1999.

5. Şahbaz M,Tel H. Determination of the relationship between the dependence status on daily living activities and home accidents among 65 years of age and older individuals living at home. Turkish Journal of Geriatrics 2006;9(2):85-93.

6. Sayın A, Candansayar S. Concept of fatigue and clinical approach to patients with fatigue. Gazi Tıp Dergisi 2007;18(1):1-8.

7. Mok CC, Cheung MY, Ho LY, Yu KL, To CH. Risk and predictors of work disability in Chinese patients with systemic lupus erythematosus. Lupus 2008;17(12):1103-7.

8. Sohng KY. Effects of a self-management course for patients with systemic lupus erythematosus. J Adv Nurs 2003;42(5):479-86.

9. Ad Hoc Committee on Systemic Lupus Erythematosus Response Criteria for Fatigue. Measurement of fatigue in systemic lupus erythematosus: a systematic review. Arthritis Rheum 2007;57(8):1348-57.

10. Krupp LB, LaRocca NG, Muir J, Steinberg AD. A study of fatigue in systemic lupus erythematosus. J Rheumatol 1990;17(11):1450-2.

11. Söderberg $S$, Lundman B, Norberg A. The meaning of fatigue and tiredness as narrated by women with fibromyal- gia and healthy women. J Clin Nurs 2002;11(2):247-55.

12. Bonner $A$, Wellard $S$, Caltabiano $M$. The impact of fatigue on daily activity in people with chronic kidney disease. J Clin Nurs 2010;19(21-22):3006-15.

13. Kozora E, Ellison MC, West S. Depression, fatigue, and pain in systemic lupus erythematosus (SLE): relationship to the American College of Rheumatology SLE neuropsychological battery. Arthritis Rheum 2006;55(4):628-35.

14. Petri M, Genovese M, Engle E, Hochberg M. Definition, incidence, and clinical description of flare in systemic lupus erythematosus. A prospective cohort study. Arthritis Rheum 1991;34(8):937-44.

15. Malcus Johnsson P, Sandqvist G, Bengtsson A, Nived O. Hand function and performance of daily activities in systemic lupus erythematosus. Arthritis Rheum 2008;59(10):1432-8.

16. Tsai YF, Chu TL, Lai YH, Chen WJ. Pain experiences, control beliefs and coping strategies in Chinese elders with osteoarthritis. J Clin Nurs 2008;17(19):2596-603.

17. Ward MM. Avoidable hospitalizations in patients with systemic lupus erythematosus. Arthritis Rheum 2008;59(2):162-8.

18. Yee CS, Farewell V, Isenberg DA, Rahman A, Teh LS, Griffiths $B$, et al. British Isles Lupus Assessment Group 2004 index is valid for assessment of disease activity in systemic lupus erythematosus. Arthritis Rheum 2007;56(12):4113-9.

19. Katz P, Morris A, Trupin L, Yazdany J, Yelin E. Disability in valued life activities among individuals with systemic lupus erythematosus. Arthritis Rheum 2008;59(4):465-73.

20. Kralik D, Koch T, Price K, Howard N. Chronic illness selfmanagement: taking action to create order. J Clin Nurs 2004;13(2):259-67.

21. Miljeteig K, Graue M. Evaluation of a multidisciplinary patient education program for people with systemic lupus erythematosus. Journal of Nursing and Healthcare of Chronic Illness 2009;1(1):87-95.

22. Schur PH. Clinic Features of SLE. Textbook of Rheumatology 1989;110-1.

23. Schepers VP, Visser-Meily AM, Ketelaar M, Lindeman E. Poststroke fatigue: course and its relation to personal and stroke-related factors. Arch Phys Med Rehabil 2006;87(2):184-8.

24. Pirbudak Çöçelli $L$, Bacaksız BD. The nurse factor in pain therapy. Gaziantep Tıp Dergisi 2008;14(2):53-8.

25. Eti Aslan F. The assessment methods of pain. Cumhuriyet Üniversitesi Hemşirelik Yüksekokulu Dergisi 2002;6(1):916.

26. Tüzün M, Aydın H, Keskin G. Systemic lupus erythematosus: HRCT findings. Tanısal ve Girişimsel Radyoloji Dergisi 2002;8(4):481-6.

27. Rabbani MA, Habib HB, Islam M, Ahmad B, Majid S, Saeed $W$, et al. Survival analysis and prognostic indicators of systemic lupus erythematosus in Pakistani patients. Lupus 2009;18(9):848-55.

28. Al Arfaj AS, Khalil N. Clinical and immunological manifestations in 624 SLE patients in Saudi Arabia. Lupus 
2009;18(5):465-73.

29. Cervera R, Khamashta MA, Hughes GR. The Euro-lupus project: epidemiology of systemic lupus erythematosus in Europe. Lupus 2009;18(10):869-74.

30. Mok CC, Ho LY, Cheung MY, Yu KL, To CH. Effect of disease activity and damage on quality of life in patients with systemic lupus erythematosus: a 2-year prospective study. Scand J Rheumatol 2009;38(2):121-7.

31. Şentürk T, Bolaman Z, Kadıköylü G. A male case with subacute cutaneous lupus erythematosus developed systemic involvement and bullous skin lesions. T Klin J Immunol Rheumatol 2003;3(2):74-7.
32. Huang HC, Chou CT, Lin KC, Chao YF. The relationships between disability level, health-promoting lifestyle, and quality of life in outpatients with systemic lupus erythematosus. J Nurs Res 2007;15(1):21-32.

33. Vargas PJ, King G, Navarra SV. Central nervous system infections in Filipino patients with systemic lupus erythematosus. Int J Rheum Dis 2009;12(3):234-8.

34. Greco CM, Rudy TE, Manzi S. Adaptation to chronic pain in systemic lupus erythematosus: applicability of the multidimensional pain inventory. Pain Med 2003;4(1):39-50.

35. Lash AA. Quality of life in systemic lupus erythematosus. Appl Nurs Res 1998;11(3):130-7. 